\title{
Mastery learning and its Impact on the performance Level in Discus Throw competition
}

\section{Dr/ Eman Ibrahim Elsisi*}

\section{Introduction and problem of the study :}

There are several instructional methods and strategies that can be way that can be used to develop the learners', sportive skills in a way that copes with their potentials and capabilities. One of these strategies is" mastery learning" it is, according to Abbas et, al (2012:222) one of the strategies that develop the learners', skills. It depends on the continuous repetition that is consistent with students', individual differences. The students', ability to learn the skill and use it is one of the principal/main conditions of mastering it.

Al Howaidi (2005: 137) pointed out that mastery learning helps provide students with instructional units that have predetermined specific objectives. Students are not allowed to move or proceed to the next stage or unit unless they master the previous one. If they do not achieve the required level, they are provided with remedial materials that enable them to achieve that level of mastery. This can not take place in classes where traditional methods and strategies are used.

Al-Far (2003:61) pointed out that the main objective of mastery learning is to increase the collection of the educated to the maximum extent possible.

$$
\text { Al-Hamdiat }
$$

(2005:2) added that remedial learning is important in mastery learning as it depends on diagnosing the learning difficulties and providing the appropriate remedy for each instructional unit, also, it includes formative assessment and permits the use of more than one method/strategy to achieve mastery learning.

It becomes evident that the teaching process, according to many educationists and authors, aims to help students achieve mastery learning. That is why the researcher attempted to use mastery learning to help

*Assistant professor, Dept. Of athletics, faculty of physical Education , Sadat City university Assiut Journal For Sport Science Arts 
students achieve mastery in their performance level of discus throw.

\section{-Aims of the study :}

The current study aims to design an instructional program based on mastery learning and investigating its effect on:

1-The skillful performance level of the participants', discus throw.

2-The digital performance level of the participants, discus throw.

\section{-Hypotheses of the study:}

1-There are statistically significant differences between the mean scores of experimental group's pre-post administrations on the skillful and digital performance levels of discus throw in favor of the post-administration.

2-There are statistically significant differences between the mean scores of the control group's pre-post administrations on the skillful and digital performance levels of discus throw in favor of the post-administration.
3-There are statistically significant differences between the mean scores of the experimental and the control groups', post administrations on the skillful and digital performance levels in favor of the experimental group's post administration.

\section{-Method and procedures :}

*Design of the study:

The researcher used the quasi-experimental design with an experimental group studying through mastery learning and a control group studying through the traditional / regular learning.

\section{*Participants of the study:}

The participants of the study included 40 female students selected purposefully from $2^{\text {nd }}$ year students, Faculty of physical education, Sadat City University. They were divided into an experimental group $(\mathrm{N}=15)$ and a control group $(\mathrm{N}=15)$.In addition, 10 students participated in the pilot study.

Table (1)

Descriptive statistics of the study participants $(\mathrm{N}=40)$ in terms of age, Length, weight and I.Q. 


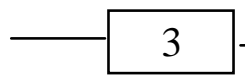

\begin{tabular}{c|c|c|c|c|c}
\hline \hline Variables & $\begin{array}{c}\text { Measuring } \\
\text { unit }\end{array}$ & Mean & Median & SD & $\begin{array}{c}\text { Bending } \\
\text { equation }\end{array}$ \\
\hline \hline age & Year & 20.44 & 2.35 & 0.61 & 0.315 \\
\hline Length & $\mathrm{Cm}$ & 162.85 & 163.00 & 4.35 & $0.225-$ \\
\hline Weight & $\mathrm{Kg}$ & 61.03 & 62.00 & 6.21 & $0.192-$ \\
\hline I.Q & degree & 26.30 & 25.50 & 3.82 & 0.106 \\
\hline \hline
\end{tabular}

Table (1) reveals that the bending equation of such variables participants of the study are was $3 \pm$ reflecting the normal equivalent / homogeneous in terms distribution of the participants in of variables such as: chronological such variables. age, Length, weight and I.Q. The

Table (2)

Descriptive statistics of the study participants $(\mathrm{N}=40)$ in physical Tests.

\begin{tabular}{l|c|c|c|c|c}
\hline \hline \multicolumn{1}{c|}{ Test Type } & M.Unit & Mean & Median & SD & $\begin{array}{c}\text { Bending } \\
\text { equation }\end{array}$ \\
\hline \hline Flexibility & Frequency & 19.95 & 20.00 & 3.11 & 0.371 \\
\hline Explosive Strength & Meter & 1.49 & 1.45 & 0.16 & 0.167 \\
\hline Accuracy & Degree & 2.33 & 2.50 & 0.79 & $0.988-$ \\
\hline Agility & Frequency & 6.24 & 6.00 & 0.68 & 0.217 \\
\hline Accordance & second & 6.68 & 6.62 & 0.85 & 0.269 \\
\hline Ability(Right arm) & Meter & 6.25 & 5.95 & 1.02 & $0.534-$ \\
\hline Ability(Left arm) & Meter & 6.12 & 6.20 & 1.27 & $0.575-$ \\
\hline (Ability(by two arm) & Meter & 5.93 & 5.70 & 1.29 & 0.390 \\
\hline \hline
\end{tabular}

Table (3)

Descriptive statistics of the study participants $(\mathrm{N}=40)$ the skillful and Digital levels on discus throw. 


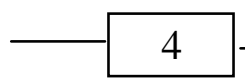

\begin{tabular}{l|c|c|c|c|c}
\hline \hline Variables & $\begin{array}{c}\text { M. } \\
\text { unit }\end{array}$ & Mean & Median & $\begin{array}{c}\text { S.D } \\
\mathbf{\pm}\end{array}$ & $\begin{array}{c}\text { Bending } \\
\text { equation }\end{array}$ \\
\hline \hline $\begin{array}{l}\text { Skillful } \\
\text { performance level }\end{array}$ & Degree & 4.03 & 4.00 & $0, \wedge 9$ & 0.636 \\
\hline Digital level & Meter & 12.75 & 13.00 & 1.01 & 0.417 \\
\hline \hline
\end{tabular}

Table (3) reveals that the study participants are equivalent/homogeneous in the skillful and digital levels on bending equation was $3 \pm$ reflecting the normal distribution of the participants in such variables.

discus throw where the

Table (4)

Mean and standard deviation (SD) of the experimental and the control groups', $(\mathrm{N} 1=\mathrm{N} 2=15)$ Pretesting on variables such as growth, I.Q, physical and skillful tests and digital level under investigation.

\begin{tabular}{|c|c|c|c|c|}
\hline \multirow[t]{2}{*}{ Variables } & \multicolumn{2}{|c|}{ Experimental } & \multicolumn{2}{|c|}{ control } \\
\hline & Mean & S.D \pm & Mean & S.D \pm \\
\hline age & 20.47 & 0.53 & 20.58 & 0.43 \\
\hline Length & 162.53 & $\overline{4.42}$ & 161.47 & $\overline{3.89}$ \\
\hline Weight & $\underline{60.93}$ & $\underline{6.15}$ & $\underline{59.40}$ & $\underline{5.99}$ \\
\hline I.Q & 28.07 & 3.63 & 25.33 & $\overline{3.84}$ \\
\hline Flexibility & 20.27 & $\overline{3.28}$ & 21.27 & $\overline{2.51}$ \\
\hline Explosive Strength & $\underline{1.52}$ & $\overline{0.17}$ & $\underline{1.45}$ & $\overline{0.18}$ \\
\hline Accuracy & $\underline{2.53}$ & $\underline{0.74}$ & 2.13 & $\underline{0.64}$ \\
\hline Agility & $\overline{6.40}$ & $\underline{0.51}$ & 6.27 & $\underline{0.88}$ \\
\hline Accordance & $\overline{6.69}$ & $\underline{1.16}$ & $\overline{6.76}$ & $\overline{0.64}$ \\
\hline Ability(Right arm) & 6.33 & $\underline{1.03}$ & 6.30 & 1.11 \\
\hline Ability(Left arm) & $\overline{6.82}$ & $\overline{0.82}$ & $\overline{6.47}$ & $\overline{0.77}$ \\
\hline (Ability(by two arm) & 5.35 & 1.00 & $\overline{5.94}$ & 1.31 \\
\hline $\begin{array}{l}\text { Skillful performance } \\
\text { level }\end{array}$ & $\underline{4.20}$ & $\underline{0.86}$ & 3.93 & $\underline{0.88}$ \\
\hline Digital level & 12.67 & $\underline{0.98}$ & $\underline{12.73}$ & 0.96 \\
\hline
\end{tabular}

Table (5) 
significance of differences between the experimental and the control Groups' pretesting on variables such as growth, I.Q,

Physical and skillful tests and digital level under investigation.

\begin{tabular}{|c|c|c|c|c|c|c|}
\hline Variables & Group & N. & $\begin{array}{c}\text { Mean } \\
\text { of } \\
\text { ranks }\end{array}$ & $\begin{array}{c}\text { Total } \\
\text { of } \\
\text { ranks }\end{array}$ & $\begin{array}{c}Z \\
\text { value }\end{array}$ & $\begin{array}{c}\text { Probable } \\
\text { error }\end{array}$ \\
\hline \multirow[t]{2}{*}{ age } & Exp. & 15 & 13.73 & 206.00 & \multirow[t]{2}{*}{1.11} & \multirow[t]{2}{*}{0.285} \\
\hline & control & 15 & 17.27 & 259.00 & & \\
\hline \multirow[t]{2}{*}{ Length } & Exp. & 15 & 16.90 & 253.50 . & 0.876 & 0.389 \\
\hline & control & 15 & 14.10 & 211.50 & & \\
\hline \multirow[t]{2}{*}{ Weight } & Exp. & 15 & 16.43 & 246.50 & \multirow[t]{2}{*}{0.584} & \multirow[t]{2}{*}{0.567} \\
\hline & control & 15 & 14.57 & 218.50 & & \\
\hline \multirow[t]{2}{*}{ I.Q } & Exp. & 15 & 19.03 & 285.50 & \multirow[t]{2}{*}{0.729} & \multirow[t]{2}{*}{0.486} \\
\hline & control & 15 & 11.97 & 179.50 & & \\
\hline \multirow[t]{2}{*}{ Flexibility } & Exp. & 15 & 14.13 & 212.00 & \multirow[t]{2}{*}{0.861} & \multirow[t]{2}{*}{0.412} \\
\hline & control & 15 & 16.87 & 253.00 & & \\
\hline \multirow{2}{*}{$\begin{array}{l}\text { Explosive } \\
\text { Strength }\end{array}$} & Exp. & 15 & 17.63 & 264.50 & \multirow[t]{2}{*}{1.33} & \multirow[t]{2}{*}{0.187} \\
\hline & control & 15 & 13.37 & 200.50 & & \\
\hline \multirow[t]{2}{*}{ Accuracy } & Exp. & 15 & 18.10 & 271.50 & \multirow[t]{2}{*}{1.77} & \multirow[t]{2}{*}{0.106} \\
\hline & control & 15 & 12.90 & 193.50 & & \\
\hline \multirow[t]{2}{*}{ Agility } & Exp. & 15 & 17.4. & $r \leqslant r . .$. & \multirow{2}{*}{$\cdot . \leqslant \vee q$} & \multirow{2}{*}{. } \\
\hline & control & 15 & $1 \leqslant . \wedge$. & TrY... & & \\
\hline \multirow[t]{2}{*}{ Accordance } & Exp. & 15 & 15.30 & 229.50 & \multirow[t]{2}{*}{0.124} & \multirow[t]{2}{*}{0.902} \\
\hline & control & 15 & 15.70 & 235.50 & & \\
\hline \multirow{2}{*}{$\begin{array}{l}\text { Ability(Right } \\
\text { arm) }\end{array}$} & Exp. & 15 & 15.20 & 228.00 & \multirow[t]{2}{*}{0.187} & \multirow[t]{2}{*}{0.870} \\
\hline & control & 15 & 15.80 & 237.00 & & \\
\hline \multirow[t]{2}{*}{ Ability(Left arm) } & Exp. & 15 & 17.20 & 258.00 & \multirow[t]{2}{*}{1.060} & \multirow[t]{2}{*}{0.305} \\
\hline & control & 15 & 13.80 & 207.00 & & \\
\hline Ability(by two & Exp. & 15 & 13.27 & 199.00 & 1.39 & 0.174 \\
\hline & control & 15 & 17.73 & 266.00 & & \\
\hline Skillful & Exp. & 15 & 16.90 & 253.50 & 0.933 & 0.389 \\
\hline $\begin{array}{l}\text { performance } \\
\text { level }\end{array}$ & control & 15 & 14.10 & 211.50 & & \\
\hline Digital level & Exp. & 15 & 15.00 & 225.00 & 0.336 & 0.775 \\
\hline & control & 15 & 16.00 & 240.00 & & \\
\hline
\end{tabular}


Tabulated $Z$ value at 0.05 level $=1.96$

Table (5) reveals that there are no statistically significant differences between the experimental and the control groups', pretesting on variables such as growth, I.Q, physical and skillful tests and digital level under investigation. This reflects the fact that both groups are equivalent / homogeneous in such variables.

Tests', validity
The researcher used the content validity as the physical tests of discus through were submitted to a panel of jury members $(\mathrm{N}=5)$ in the field of teaching and training athletics to verify their validity. The percentage of validity amounted to $100 \%$

\section{Tests' Reliability}

The following table (6) shows the correlation coefficient between the first and the second administrations of the tests.

Table (6)

the correlation co-efficient between the first and the second administrations of the tests on the variables of I.Q, physical tests and performance level.

\begin{tabular}{l|c|c|c|c|c}
\hline \hline \multirow{2}{*}{ Variables } & \multicolumn{2}{c|}{$\begin{array}{c}\mathbf{1}^{\text {st }} \\
\text { administration }\end{array}$} & \multicolumn{2}{c|}{$\begin{array}{c}\mathbf{2}^{\text {nd }} \\
\text { administration }\end{array}$} & $\begin{array}{c}\text { Correlation } \\
\text { coefficient }\end{array}$ \\
\cline { 2 - 5 } & Mean & S.D \pm & Mean & S.D \pm & \\
\hline \hline I.Q & 25.10 & 3.35 & 24.30 & 2.91 & $0.955^{*}$ \\
\hline Flexibility & 17.50 & 1.50 & 17.40 & 1.35 & $0.927^{*}$ \\
\hline Explosive Strength & 1.49 & 0.09 & 1.47 & 0.08 & $0.972^{*}$ \\
\hline Accuracy & 2.40 & 0.84 & 2.20 & 0.79 & $0.702^{*}$ \\
\hline Agility & 5.95 & 0.49 & 6.10 & 0.39 & $0.878^{*}$ \\
\hline Accordance & 6.56 & 0.64 & 6.55 & 0.66 & $0.997^{*}$ \\
\hline Ability(Right arm) & 6.03 & 0.94 & 5.86 & 0.85 & $0.978^{*}$ \\
\hline Ability(Left arm) & 4.57 & 1.15 & 4.53 & 1.10 & $0.995^{*}$ \\
\hline (Ability(by two arm) & 6.78 & 1.27 & 6.76 & 1.25 & $0.992^{*}$ \\
\hline Skillful performance level & 3.90 & 0.99 & 4.40 & 0.84 & $0.715^{*}$ \\
\hline \hline
\end{tabular}

* Tabulated $\mathbf{R}$ value at 0.05 level $=0.576$

Table (6) reveals that there is a statistically significant correlation between the first and the second administration on I.Q, physical tests and skillful performance level at the 0.05 level. This reflects that the tests were reliable.

Assiut Journal For Sport Science Arts 
*The instructional program based on mastery learning strategy.

\section{Aim of the program:}

The program aims to teach discus throw to physical education students at Sadat City University through using mastery learning.

\section{Content of the program}

The content of the program included a group of instructional materials that include the following:

1-Teacher verbal explanation accompanied by the demonstrations.

2- Teacher verbal explanation technical stages of the discus throw (catch
The discus- swing the discusrotation-Throwing - Balance) by using $C D$.

3-Students experimental group $80 \%$ women who did not achieve their desired goal of providing them with the other educational alternatives to a compact disc (CD), and transparencies.

4-Students in the experimental group women who have achieved $80 \%$ or more of the desired goal was their distribution to the rest of the students as leaders for them 5- The use of Constant images showing the technical stages of the discus throw.

6- The use of Motion pictures showing the technical stages of the discus throw

\section{Distribution of units proposed of educational program}

\begin{tabular}{ccccc}
\hline \hline $\begin{array}{c}\text { Unity } \\
\text { time }\end{array}$ & $\begin{array}{c}\text { The number } \\
\text { of units per } \\
\text { week }\end{array}$ & $\begin{array}{c}\text { The number of } \\
\text { units in the } \\
\text { program }\end{array}$ & $\begin{array}{c}\text { The number } \\
\text { of weeks } \\
\text { the program }\end{array}$ & $\begin{array}{c}\text { Number of } \\
\text { months of } \\
\text { the program }\end{array}$ \\
\hline \hline $90 \mathrm{~s}$ & 3 units & 12 units & 4 weeks & a month \\
\hline \hline
\end{tabular}

\section{Results and discussion:}

1-Results and discussion of first hypothesis:

\section{Table (7)}

Means and SDs of the experimental group`s $(\mathrm{N}=15)$ pre- post administrations in skillful and digitals levels of Discus throw.

\begin{tabular}{l|c|c|c|c}
\hline \hline \multirow{2}{*}{ Variables } & \multicolumn{2}{c|}{$\begin{array}{c}\text { Pre- } \\
\text { administration }\end{array}$} & \multicolumn{2}{c}{ Post- administration } \\
\cline { 2 - 5 } & Mean & S.D \pm & Mean & S.D \pm \\
\hline $\begin{array}{l}\text { Skillful performance } \\
\text { level }\end{array}$ & 4.20 & 0.86 & 8.60 & 0.63 \\
\hline Digital level & 12.67 & 0.98 & 18.40 & 1.96 \\
\hline \hline
\end{tabular}


Table (8)

significance of the differences between the experimental group's pre-post administrations in skillful and digital levels of discus

throw.

\begin{tabular}{|c|c|c|c|c|c|c|c|}
\hline \multirow[t]{2}{*}{ Variables } & \multirow[t]{2}{*}{ administration } & \multicolumn{2}{|c|}{ difference } & \multirow{2}{*}{$\begin{array}{r}\text { Ranks } \\
\text { mean }\end{array}$} & \multirow{2}{*}{$\begin{array}{c}\text { Ranks } \\
\text { sum }\end{array}$} & \multirow{2}{*}{$\begin{array}{c}\mathrm{Z} \\
\text { value }\end{array}$} & \multirow{2}{*}{$\begin{array}{l}\text { Error } \\
\text { probability }\end{array}$} \\
\hline & & Attitude & Number & & & & \\
\hline \multirow{2}{*}{$\begin{array}{l}\text { Skillful } \\
\text { performance } \\
\text { level }\end{array}$} & Pre & - & 0 & 0.00 & 0.00 & \multirow[t]{2}{*}{$3.44 *$} & 0.001 \\
\hline & Post & + & 15 & 8.00 & 120.0 & & \\
\hline \multirow[t]{2}{*}{ Digital level } & Pre & - & 0 & 0.00 & 0.00 & $3.44 *$ & \multirow[t]{2}{*}{0.001} \\
\hline & Post & + & 15 & 8.00 & 120.0 & & \\
\hline
\end{tabular}

*Tabulated $\mathrm{Z}$ value at 0.05 level $=1.96$

Table ( 8 ) reveals that there are differences between the experimental group`s pre - post administrations in skillful and digital performance levels of discus throw owing to mastery learning in favor of the postadministration. This is attributed to the use of mastery learning including recent instructional media that attract the students' attention through using computers. Also it included a series of pictures that had a positive effect on learning faster and correcting mistakes and /or errors. In this respect, Abu Harga et .al (2001:19) pointed out that using instructional media

provide two main conditions of learning, namely learners' active participation and feedback and this, in turn, leads to developing kinetic performance. Also, Ibrahim (2002:94) pointed out that mastery learning helps the majority of students achieve the required learning level. In addition, Tarek and Mekhlef (2001:230) stated that mastery learning stimulates the learners' , motivation, provides sufficient time for learning and does not allow the learners to move from one step/stage to another unless they achieve mastery. 
2- Results and discussion of second hypothesis:

Table (9)

Means and SDs of the control group`s $(\mathrm{N}=15)$ pre- post administrations in skillful and digital levels of Discus throw.

\begin{tabular}{|c|c|c|c|c|}
\hline \multirow[t]{2}{*}{ Variables } & \multicolumn{2}{|c|}{$\begin{array}{c}\text { PER- } \\
\text { ADMINSTRAION }\end{array}$} & \multicolumn{2}{|c|}{$\begin{array}{c}\text { POST- } \\
\text { ADMINSTRAION }\end{array}$} \\
\hline & Mean & S.D \pm & Mean & S.D \pm \\
\hline $\begin{array}{l}\text { Skillful } \\
\text { performance level }\end{array}$ & 3.93 & 0.88 & 6.93 & 1.28 \\
\hline Digital level & 12.73 & 0.96 & 16.00 & 1.19 \\
\hline
\end{tabular}

Table (10)

significance of the differences between the control group`s prepost administrations in skillful and digital levels of discus throw.

\begin{tabular}{|c|c|c|c|c|c|c|c|}
\hline \multirow[t]{2}{*}{ Variables } & \multirow[t]{2}{*}{ admiration } & \multicolumn{2}{|c|}{ DIFFERENCE } & \multirow{2}{*}{$\begin{array}{c}\text { Ranks } \\
\text { mean }\end{array}$} & \multirow{2}{*}{$\begin{array}{c}\text { Ranks } \\
\text { sum }\end{array}$} & \multirow{2}{*}{$\begin{array}{c}\mathbf{Z} \\
\text { value }\end{array}$} & \multirow[t]{2}{*}{ Error } \\
\hline & & Attitude & Number & & & & \\
\hline \multirow{2}{*}{$\begin{array}{l}\text { Skillful } \\
\text { performance } \\
\text { level }\end{array}$} & Pre & - & 0 & 0.00 & 0.00 & \multirow[t]{2}{*}{3.46} & 0.001 \\
\hline & Post & + & 15 & 8.00 & 120.0 & & \\
\hline \multirow[t]{2}{*}{ Digital level } & Pre & - & 0 & 0.00 & 0.00 & 3.45 & \multirow[t]{2}{*}{0.001} \\
\hline & Post & + & 15 & 8.00 & 120.0 & & \\
\hline
\end{tabular}

*Tabulated $\mathrm{Z}$ value at 0.05 level $=1.96$

Table (10) reveals that there are differences between the control group's per - post administration in skillful and digital levels of discus throw in favor of the postadministration .The researcher attributed such differences to the role of the traditional method in verbal explanation and practical demonstration ( by the teacher) of discus throw race.

In this respect, Barhoom (2013:35) pointed out that the traditional method is not costly, can be used in overcrowded classes and can be easily applied to the various educational stages. Also, Ibrahim (2002:396) stated that learning, in the traditional method, takes place through lecturing and transmission. The learner attempts to avoid making mistakes while the teacher teaches all students the same without paying attention to individual differences.

In addition, Rayan (2004:128) and Abdel karim (2006:248)

Assiut Journal For Sport Science Arts 
stated that the traditional method is direct and helps in transmitting information from the teacher to students in a quick and easy manner. Also,

the teacher dominates the teaching- learning situation and the classrooms are teacher centered.

2- Results and discussion of third hypothesis:

Table (11) Means and CDs of the experimental and the control group`s $(\mathrm{N} 1=\mathrm{N} 2=15)$ post administrations in skillful and digital levels of Discus throw.

\begin{tabular}{l|c|c|c|c}
\hline \hline \multirow{2}{*}{ Variables } & \multicolumn{2}{|c|}{ Experimental } & \multicolumn{2}{c}{ Control } \\
\cline { 2 - 5 } & M. & S.D \pm & M. & S.D \pm \\
\hline \hline Skillful performance level & 8.60 & 0.63 & 6.93 & 1.28 \\
\hline Digital level & 18.40 & 1.96 & 16.00 & 1.19 \\
\hline \hline
\end{tabular}

Table (12) significance of the differences between the experimental and the control group's post administrations in skillful and digital levels of discus throw.

\begin{tabular}{l|c|c|c|c|c|c}
\hline \hline Variables & admiration & $\mathbf{N}$ & $\begin{array}{c}\text { Ranks } \\
\text { mean }\end{array}$ & $\begin{array}{c}\text { Ranks } \\
\text { sum }\end{array}$ & $\begin{array}{c}\mathbf{Z} \\
\text { value }\end{array}$ & $\begin{array}{c}\text { Error } \\
\text { probability }\end{array}$ \\
\hline \hline \multirow{2}{*}{$\begin{array}{l}\text { Skillful } \\
\text { performance } \\
\text { level }\end{array}$} & Exp. & 15 & 20.93 & 317.0 & $3.53^{*}$ & 0.000 \\
\cline { 2 - 5 } & control & 15 & 10.07 & 151.0 & & \\
\hline Digital level & Exp. & 15 & 20.67 & 310.0 & $3.86^{*}$ & 0.001 \\
\cline { 2 - 5 } & control & 15 & 10.33 & 155.0 & & \\
\hline \hline
\end{tabular}

*Tabulated $\mathrm{Z}$ value at 0.05 level $=1.96$

Table (12) reveals that there are differences between the experimental and the control groups', postadministration in skillful and digital levels of discus throw in favor of the experimental group.

The researcher attributed the experimental group's improvement to the various sources of feedback through the various instructional materials that included the teacher' presentation, computer animation and stable pictures. Al-Far (2000:61-62)pointed out that mastery learning stimulates the learner's motivation and drives her to depend on herself and interact actively with the available 
experience sources, thereby enabling her to acquire and learn the required knowledge and skills .AL-Hila(2001 : 271) asserted that mastery learning focuses on mastering each unit before moving to the next unit, This might take place through testing students on that unit to make sure they have learnt and mastered it .As for the other students who have not achieved mastery, they receive remedial teaching and activities after which they are retested. When they achieve mastery, they join their good colleagues.

Also, Al-khatib (2001:82) emphasized that mastery learning provides students with ample time for learning and various alternative methods of learning if one proved ineffective and not successful.

\section{Conclusions:}

To conclude, mastery learning proved effective and successful in helping students of the experimental group to improve their performance level in discus throw. Statistically significant differences appeared in favor of the experimental group students due to the use of mastery learning.

\section{Recommendations:}

It is recommended that:

1-New methods and strategies of teaching should be used instead of the traditional ones.

2-Mastery learning should be used in teaching and learning other athletic/sport activities.

\section{References:}

1- Abbas,S.;Khalil,M. and Ghanawi (2012) The effect of using Mastery learning on developing the skill of shooting from a standing position in basket ball, Faculty of physical Education, Dialy university, AL-Fath Magazine ,51.

2- Abdel-karim, M. (2006)

Dynamics of teaching physical Education, center of book publishing, Cairo.

3- Abu Harga, M.; Zaghlol, M.; Saed, H. (2001) Educational Technology and styles of physical Education, center of book. Publishing, Cairo.

4- Al-Far, I. (2003) Methods of teaching computers, $1^{\text {st }}$ edition, Al-Fikr publishing House, Amman, Jordan.

5- Al-Far, I. (2000) computer and and the challenges of the early twenty-first century, Eye, University Book House.

6- AL-Hamdiat, M. (2005)

learning for Mastery in 
Mathematics,

Teacher

Magazine, AL-kataan center

for Research and Educational

Development, GAZZA.

7- Al-Hila, M. (2001).

Methods of Teaching and strategies, $\quad 1^{\text {st }}$ edition, University book - publishing House.

8- Al-Khatib, L. (2001). Modern Educational Technologies Erbid, Al-kindi Bookshop.

9- Barhoom ,A.(2013) Effect of blended learning on developing concepts and skills of using technological innovation incorporated in "Educational Technology "course among female students in faculty of Education Islamic university .M.A Thesis,

Gazza.

10- Howeidi, z. (2005)

.Effective Teaching, university bookshop, Al-Ain Emirates.

Ibrahim, F. (2002) learning for Mastery strategy Educational Mission, I, Muscat, MOE, Oman.
11- Ibrahim, M. (2002) • Effective Teaching, Definition, skills and Management, Anglo Bookshop, Cairo.

12- Rayan, F. (2004). Teaching: Aims, Foundations, Evaluating outcoms, Applications .Book words, Cairo.

Tarek, A.and Mekhlef, A. (2001) Educational Thought in Al-Ghazali and Al-Kapsi, Faculty of education Journal, 8, Al-Mustanseria universality. 